\title{
Experimental animal models for retinal and choroidal diseases
}

\begin{abstract}
Experimental animal models have critical importance for the recognition and the management of various retinal and choroidal diseases. To date, they were described for the induction of melanoma and neovascularization of choroid, degenerations, and detachment in the retina, proliferative vitreoretinopathy, diabetic and hypertensive retinopathy, preretinal neovascularization, central serous chorioretinopathy, retinopathy of prematurity (ROP) or $\mathrm{O}_{2}$ induced retinopathy (OIR) and retinoblastoma. The aim of this review is to provide an overview of experimental animal models for retinal and choroidal diseases. To know the most favorite models and animals for these diseases will provide many utilities to the researchers in their experimental studies and thesis.
\end{abstract}

Volume 7 Issue 4 - 2017

Burak Turgut, Feyza Caliș Karanfil

Department of Ophthalmology, Yuksek Ihtisas University, Turkey

Correspondence: Burak Turgut, Professor of Ophthalmology, Faculty of Medicine, Department of Ophthalmology, Yuksek Ihtisas University, 06520, Ankara, Turkey, Tel +90 312 280360I, Email drburakturgut@gmail.com

Received: August 24, 2017| Published: October 04, 2017

Keywords: experimental, animal models, retinal, choroidal, diseases

\section{Introduction}

Experimental animal models have an important place in medical research for the development of new therapeutic strategies in the treatment of the ocular diseases in humans. The aim of using animal models in ocular experiments is to achieve the easiness in the understanding of the pathophysiology of the diseases and to determine the specific treatment protocols for the diseases. Currently, a number of animal models are available for various choroidal and retinal diseases. ${ }^{1-6}$ The researchers should be the choice to use the adequate animal model having the closest homology with human anatomy and pathology at the setting stage of their studies. The aim of this review is to give the general information on experimental animal models for various retinal and choroidal diseases and to provide the methods and techniques for researchers regarding experimental procedures in animals.

\section{Choroidal malign melanoma}

Choroidal melanoma is the most common primary malignant intraocular tumor and the second most common primary malignant melanoma in adults. It has been considered that the mouse model is the best in the immunologic studies while as rabbit model is more useful in the therapeutic studies for experimental choroidal melanoma. B16F10 melanoma cell lines originally isolated from melanotic tumors are used to establish choroidal melanomas. Tumor cells are implanted transclerally into the choroid. B16F10 melanoma cell line has also the more metastasis compared the other melanoma cell lines. ${ }^{4-13}$

\section{Choroidal neovascularization (CNV) and neovascular age related macular degeneration (n-AMD)}

Age-related macular degeneration (AMD) is a leading cause of irreversible visual loss in over 65 years old. Neovascular AMD is responsible for $90 \%$ of cases with severe vision loss from hemorrhage and fibrosis and it is characterized by CNV that is developed due to a rupture in the Bruch membrane. The induction of the neovascular AMD in an animal model is not easy. The animals having a macula are only the primates. Although the mechanical rupture of Bruch's membrane with laser photocoagulation (LFC) can stimulate CNV in primates, rabbits, and rodents, these usually improve spontaneously. Additionally, the recent studies in transgenic mice demonstrated that the neovascularization (NV) originated from the inner side of the retina but not from the outer side. ${ }^{14-24}$ However, it has been recently developed an Ad vector encoding human VEGF to induce CNV. In this model used the Long-Evans rats, CNV developed two weeks following the subretinal injection of the viral vector (Table 1). ${ }^{25}$

Table I Experimental disease and most favorite animal for experimental retinal and choroidal diseases

\begin{tabular}{ll}
\hline $\begin{array}{l}\text { Experimental ocular } \\
\text { disease }\end{array}$ & $\begin{array}{l}\text { Favorite animal for } \\
\text { experimental model }\end{array}$ \\
\hline Choroidal melanoma & Rabbit, Mouse \\
CNV and neovascular AMD & $\begin{array}{l}\text { Primates, Rodents } \\
\text { Retinal detachment }\end{array}$ \\
PVR & Mouse \\
Diabetic Retinopathy & Ratents \\
Preretinal neovascularization & Rabbit \\
CSCR & Monkey \\
Hypertensive retinopathy & Dog, Monkey \\
ROP or OIR & Mouse, Rat \\
Retinoblastoma & Mice, Murine \\
Retinal degeneration & Mice, Rat, Zebrafish \\
RIR & Rodent \\
CRVO & Rat \\
CRAO & Rat \\
\hline
\end{tabular}

CNV, choroidal neovascularization; AMD, age related macular degeneration; PVR, proliferative vitreoretinopathy; CSCR, central serous chorioretinopathy; ROP, retinopathy of prematurity; OIR, oxygene induced retinopathy; CRVO, central retinal vein occlusion; CRAO, central retinal artery occlusion; RIR, retinal ischemia-reperfusion 
$\mathrm{CNV}$ induction can be performed with a slit lamp delivery system using Argon green LFC (100 $\mu \mathrm{m}$ spot size, $180-300 \mathrm{~mW}$ power, and 0.1 second duration) or Diode LFC $(100 \mu \mathrm{m}$ spot size, $150-180 \mathrm{~mW}$ power and 0.1 second duration) at the localization such as 8 regions between the major blood vessels in each eye or four LFC burns in each eye at the positions of 3, 6, 9, and 12 o'clock, almost two discs diameters from the optic nerve head. The observation of an acute vaporization or cavitation bubble indicates the rupture of Bruch's membrane. A spot size of $50 \mathrm{~mm}$ and duration of $100 \mathrm{~ms}$ has been most widely used in nonhuman primates. ${ }^{19,20,22}$ Although LFC power may show a variation as a range between $240 \mathrm{~mW}$ and $1500 \mathrm{~mW}$, the LFC power of $300-700 \mathrm{~mW}$ are most commonly used..$^{18,22,26}$ However, it has been choiced multiple and repeated LFC applications at the same spot or an immediately adjacent one to provide Bruch's membrane rupture. The indicator of the perforation of Bruch's membrane is a heard of a voice of "pop" and the observation of a sub retinal bubble. Although, early studies showed that laser-induced CNV in non-human primates is low incidence, recent studies demonstrated that $\mathrm{CNV}$ incidence following LFC of the macula increased. ${ }^{18-20,22,27}$ The physiology and anatomy of human and nonhuman primate eyes are so similar. Thus, the primate laser-induced CNV models in rhesus and cynomolgus monkeys have been choiced for preclinical evaluation of n-AMD treatment options. ${ }^{19,21,22,26}$ Except for the LFC induced CNV, the subretinal NV has been formed in transgenic mice through the increased expression of vascular endothelial growth factor in the retina. ${ }^{23}$

\section{Retinal detachment (RD)}

The animal RD models are important in the evaluation of the pathogenesis of the disease and new treatment methods in RD. ${ }^{28-40}$ Many studies have used the mouse as a model to study retinal detachment/reattachment. Mouse eye is a good model for the experimental eye diseases because its manupilation is easy. ${ }^{41-44}$ In animal RD models, manual peeling off the neuroretina from the retina pigment epithelium (RPE) and the subretinal injection of saline, balanced salt solution, phosphate-buffered saline (PBS), hyaluronate or RPE cells have been used to establish an experimental RD in rodent eyes and provide the pathologic features of human RD. ${ }^{45-54}$ The subretinal injection of sodium hyaluronate has some advantages such as no known ocular toxicity and the long duration of RD compared to others. The subretinal injection of sodium hyaluronate may performed with a trans vitreal or a trans scleral way with the observation of the fundus. ${ }^{28,29,32-34,40}$ In the trans-vitreal method, a sub retinal injector is introduced into the vitreous cavity, a peripheral retinotomy is created, and the sodium hyaluronate is injected into the subretinal space. In this method, two retinal tears are created to increase the risk of retinal hemorrhage. Subretinal hemorrhage or hemorrhage entered underneath the retina is toxic for photoreceptor cells through retinal hypoxia and metabolic impairment due toits diffusion barrier effect, and toxicity due to iron in blood in the detached retina. This induces retinal degeneration and $\mathrm{RD}$. $^{28,29,32-34,40}$

In trans-scleral method, a $30 \mathrm{G}$ needle with a syringe containing sodium hyaluronate is inserted into the subretinal space through the conjunctiva, sclera, choroid, and RPE following reduction of intraocular pressure (IOP) with an anterior chamber parasenthesis. The sodium hyaluronate is then injected into the subretinal space..$^{32,33,37}$ The incidence of retinal tear and lens injury in transscleral method is less compared to that in the trans-vitreal method. As the sclera puncture by a $30 \mathrm{G}$ needle may be large for mouse eyes, the reflux from scleral hole of sodium hyaluronate injected into the subretinal space may easily occur. Thus, this may cause to establish a lower and less persistent RD. ${ }^{45-54}$

\section{Proliferative vitreoretinopathy (PVR)}

Proliferative vitreoretinopathy is one of the most important complications experienced by vitreoretinal surgeons and one of the most important causes for serious vision loss worldwide. It is an abnormal tissue response characterized by the proliferation of non-neoplastic cells within the vitreous gel and on retinal surfaces, resulting in contractile membrane formation and the retinal traction. ${ }^{55,56}$ Currently, the most widely used models of PVR in animals are the intravitreal injection of RPE cells or dispase. PVR induction by the injection of RPE cells cultured from healthy, homologous eyes or tissue in balanced salt solution is performed using with a 30-gauge needle, $4 \mathrm{~mm}$ posterior to the limbus into the vitreous cavity. ${ }^{55-58}$ The PVR model formed by intravitreal injection of dispase, a proteolytic enzyme derived from Bacillus polymyxa, is an easy and cheap method. ${ }^{58}$ Dispase selectively disrupts type 4 collagen and fibronectin in the structure of the basement membrane which plays acritical role in the continuity of RPE cell layer. In recent studies, it was shown that an effective dose of dispase is $0.05-0.07 \mathrm{U}$ and that average duration is $8-10$ weeks for PVR development. ${ }^{58,59}$

Histopathological assessment of the sections from Labrador Retriever revealed a fibro-cellular membrane formation containing RPE cells, ciliary epithelial cells and glial cells on detached retina. ${ }^{60}$ It is considered that this PVR model is unique spontaneous PVR model similar to the human PVR. In the past, formation of retinal hole with endodiathermy in the inferior retinal quadrants at equatorial line with following lensectomy and vitrectomy has been commonly used to establish an experimental PVR. ${ }^{61}$ A combination of retinotomy, incomplete vitrectomy, and retinal criopexy or only the intravitreal injection of fibroblast or thrombocyte on optic nerve head have been also used for the same purpose in rabbits and porcine. ${ }^{62-65}$ In a recent study, it has been reported that PVR might also be induced in domestic swine by creation of a posterior vitreous detachment, creation of a retinal detachment by the injection of subretinal fluid, and intravitreal injection of green fluorescent protein-positive RPE cells. ${ }^{57}$

\section{Diabetic retinopathy (DR)}

Diabetic retinopathy is currently one of the leading causes of blindness over the world. The use of animal models of DR is very important for understanding the pathogenesis of disease and for the development of specific and effective treatment modalities for DR. Currently, there are various animal models of DR and the earliest retinal pathologies could be developed in these. However, none of these models has been the success to mimic fully human DR. The animal models of DR which were used most commonly are rats and mice. However, currently, the zebrafish DR model is a promising option. Nonhuman primates and humans have similar eye structures, and both can develop spontaneous diabetes mellitus (DM). ${ }^{66-68}$ There are four options using for the induction of DM in rodents: injection of streptozotocin (STZ) or alloxan, pancreatectomy, genetic modification and galactose diet. Streptozotocin or alloxan induces hyperglycemia and causes the destruction of pancreatic beta cells and subsequently insulin deficiency and Type $1 \mathrm{DM}$. This is the main diabetic retinopathy model in the rats. However, preretinal neovascularization, microaneurysms, and intraretinal vascular abnormalities are not detected in these rat models. On the other hand, vascular events in non-proliferative diabetic retinopathy (NPDR) 
such as loss in the capillaries and their cells such as pericyte in the capillary, and thickening at the basement membrane can be developed in rats with STZ or alloxan induced diabetes after six months from the onset of diabetes. ${ }^{66-69}$

In rats, it has been used to provide experimental DR formation via the administration of STZ-all-oxane, supplementation with hypercaloric diet (for seven months), leptin receptor gene mutation (spontaneously). In mice, the administration of STZ, supplementation with hypercaloric diet (for 21-26 months), gene mutation (spontaneously) may be a choice for the same purpose. ${ }^{66-69}$ Zebrafish (Danio rerio), a small freshwater fish species which originated in the Ganges River, are currently commonly used as an adequate experimental model to study the genetic, cellular, and molecular mechanisms of various human diseases. ${ }^{70}$ They have similar blood glucose and pancreatic islet cells with human. Thus, intraperitoneal STZ injection and water with glucose $2 \%$ may be used to induce DR. ${ }^{66-70}$ Additionally, experimental DR has been formed with pancreatectomy, administration of STZ-all-oxane, 30\% galactose diet (over 36 months) in dogs, administration of STZ-alloxane in porcine, pancreatectomy in cats and administration of STZ (15 years) in primates. ${ }^{65,67}$

\section{Preretinal/retinal neovascularization (NV)}

Severe retinal NV is responsible for severe visual loss in various retinal diseases such as DR, retinal vein occlusion (RVO), and ROP. Many investigators have attempted to induce retinal NV experimentally by intravitreal injection of dermal fibroblasts, intravitreal implants impregnated with Interleukin-1, laser photocoagulation of retinal veins, and hyperoxygenation, intravitreal tumor cell implantation and intravitreal preparation of cultured fibroblasts on rats also develop retino-vitreal NV. ${ }^{71-85}$

\section{Central serous chorioretinopathy (CSCR)}

Central serous chorioretinopathy is characterized by serous detachment of the neurosensory retina and/or RPE frequently in the macular region. Recurrent or chronic detachment is often associated with more diffuse retina pigment epitheliopathy, which is resulted in RPE atrophy, macular degeneration, foveal atrophy and secondary sub-retinal NV. ${ }^{86}$ The pathogenesis of CSCR is unknown. However, it has been considered that the CSCR may be due to focal RPE defect or choroidal lobular ischemia and choroidal venous congestion. Although there are various risk factors for the development of CSCR, psychosomatic factors and the increased levels of serum catecholamine or both have been thought to have important role in the pathogenesis of CSCR. Yannuzzi considered that type A personality might be strongly associated with the sympathetic release in CSCR and that macula was the target tissue for this pathology. In the previous studies, it has been suggested that CSCR could be created by intravenous epinephrine in the experimental monkey model. It has been observed disciform retinal detachment after 2 months following administration IV epinephrine and prednisolone.It was postulated that elevated catecholamine levels in patients with CSCR might cause choroidal vasoconstriction by activating the sympathetic nervous system. It was also considered that the elevation of choroidal hydrostatic pressure caused by choroidal vasoconstriction leads to the breakdown of tight junctions among RPE cells, allowing fluid to pass from the choroid to the subretinal space. ${ }^{87-93}$

\section{Hypertensive retinopathy}

Hypertensive retinopathy refers to changes in the retina in response to elevated blood pressure (BP). Hypertensive retinopathy is broadly divided into different stages, including vasoconstrictive, sclerotic, exudative, and malignant hypertension phases. ${ }^{94}$ In fact, hypertensive retinopathy signs are detected frequently in persons without a known history of hypertension. ${ }^{94}$ Experimental studies on hypertensive retinopathy have been performed on rodents, dogs, and monkeys. Experimental hypertension in dogs and monkeys has been created surgically to form the renal ischemia. Spontaneous hypertension has been frequently reported in dogs and cats. The hypertension model with complete or partial renal artery occlusion has established acute hypertension model in humans. ${ }^{95-98}$ Animal models, in vitro experiments, and clinical studies have demonstrated that microcirculatory changes such as arteriolar narrowing, enhanced vasoconstriction, reduced vasodilator responses and arteriolar or capillary diminishing are the earliest changes in the pathogenesis of hypertension. It has been considered that the microcirculation plays a critical role in the pathogenesis of hypertension. ${ }^{99-104}$

\section{Retinopathy of prematurity (ROP)/O2 induced retinopathy (OIR)}

Retinopathy of prematurity is one of the most common causes of visual loss which could lead to blindness from fibrovascular $\mathrm{RD}$ in childhood. Recent studies in OIR animal models have been demonstrated that high oxygen levels, oxidative stress, and inflammation cause ROP via dysregulation in hypoxia inducible factors and angiogenic factors, neuroprotective growth factors and oxidative molecules. ${ }^{105}$ Most OIR models provide some features of human ROP because healthy newborns but not premature animals were used in these models. The most commonly used animals for OIR model are mouse and rat. ${ }^{105-107}$ However, various animal species, including rat, mouse, beagle puppy, and zebrafish have been used as animal models of OIR. ${ }^{106-110}$ Human and animal models have some differences regarding the stages of OIR. Human ROP phases include "early phase" (stages 1 and 2 ROP with delayed physiologic retinal vascular development and partial vaso-obliteration), "vascular phase" (intravitreal NV, stage 3 ROP with plus disease) or "fibrovascular phase" (stages 4 and 5 ROP with RD). OIR Phase 1 in the rat and mouse conform the "early phase" of ROP in human (delayed physiologic retinal vascular development and vaso-obliteration, respectively). OIR Phase 2 in the rat and mouse models conform the vaso-proliferative intravitreal NV like "vascular phase" of stage 3 ROP with plus disease in humans. The beagle OIR model can show some features such as retinal folds and dragging of retinal vessels seen in stage 4 human ROP. ${ }^{111-116}$

In mouse OIR model, C57BL/6J mice with 1 -week-old are exposed to $75 \%$ oxygen for 5 days and then they are returned to room air. ${ }^{106}$ Significantly retinal NV occurs between postnatal days 17 and 21 . The rats have been also used for this purpose. ${ }^{107,108,117,118}$ The transgenic mice may also be used in the mouse OIR model. These may be more helpful to study vaso-attenuation caused by hyperoxia and vascular regrowth into the retina or vitreous following the return to relative hypoxia. ${ }^{106}$ The most favorite OIR model is the rat OIR model because it has features of both central retinal vaso-attenuation and delayed physiologic peripheral retinal vascularization. ${ }^{107,108,117}$ In another OIR model, newly born pups and dams are placed into 
a controlled oxygen environment and exposed oxygen levels from $50 \%$ to $100 \%$ every 24 hours for 14 days. This hyperoxia provides the increase of arterial oxygen similar to that in a human preterm infant with severe ROP. ${ }^{119,120}$ The appearance of first delayed physiologic retinal vascular development followed by intravitreal NV at the junction of the vascular and avascular retina at day 18 is similar to type 1 severe ROP. ${ }^{121}$ Thus, the rat OIR model closely represents human preterm infants with severe ROP. The beagle OIR modelhas more similarity to the human preterm infant eye than the newborn rodent regarding the sizes of the eyes. The retina of a newborn beagle initially vascularizes via vasculogenesis and then angiogenesis like that occurs in premature human infant retina. However, the model uses very high oxygen to cause OIR, which differs from the pathogenesis of ROP in most premature infants. In the beagle model, newborn pups are placed into $100 \%$ oxygen in day 1 postnatal for 4 days and then returned to room air for recreating the phases of OIR. ${ }^{111,112-118}$

\section{Retinoblastoma (RB)}

Retinoblastoma is the most common ocular tumor of malignant childhood and it is fatal if left untreated. Great majority of RB cases are diagnosed by 3 years of age. It has been reported that in RB, the development of tumor is caused by mutations in the retinoblastoma gene $(\mathrm{pRb})$ in some animals such as primates and fishes., ${ }^{422-132}$ Additionally, the mice RB model has been developed with on cogenesis induced by the usage of nickel and viruses. ${ }^{133}$ The RB animal models in murine and mice are genetic mutation (gene knockout) models and xenograft models. Transgenic models of RB include LH-beta T-Ag models an RB knockout model. ${ }^{129}$ The histopathological phenotypic changes in RB gene knockouts with an additional loss of p107, p130, p53 and using promoters of Nestin, Chx10, and Pax6 genes are very similar to those of human RB. ${ }^{129-133}$

\section{Retinal degeneration}

In the animal models of retinal cell degeneration, degeneration includes transient ischemia-induced retinal cell degeneration; degeneration of retinal ganglion cells (RGC), photoreceptor cells and amacrine cells; glutamate release and N-methyl-D-aspartate (NMDA)/non-NMDAreceptor activation, activation of TNF/TNF-R system. ${ }^{134-136}$ In inherited retinal degeneration model, a gene mutation or the expression of a transgene is used to provide retinal degeneration. Gene mutations can appear spontaneously as those in the rd1 (retinal degeneration 1) mouse. The RCS (Royal College of Surgeon) rat may also be used for same purpose. This one shows a functional deficiency in the MerTK gene. Additionally, dogs and cats have been used for inherited model generally. ${ }^{134}$ Currently, Zebrafish model is a more popular option for the establishment of the animal retinal degeneration because this fish species can be efficiently and easily mutagenized by the addition of the alkylating agent ethyl nitrosourea (ENU) to the water. Additionally, the cloning of the disrupted gene via viral insertion mutagenesis of a mutating agent such as a pseudo typed virus is an option for this purpose. ${ }^{137,138}$

Alternatively, the transient knockdown of a protein of choice by morpholino antisense technology, modified (morpholino) antisense nucleotides can be used for same purpose. In this model, these nucleotides interfere the blockage of translation initiation, or with splice sites, and cause aberrant splicing and hence nonfunctional mRNA. ${ }^{139,140}$ In in vivo retina ischemia models, degeneration of retinal ganglion cells (RGC), photoreceptor cells and amacrine cells, retinal degeneration is established by the induction and progression of photoreceptor cell death via the exposure of wild-type or genetically engineered animals such as mice and rats to light or N-methyl-Nnitrosourea (MNU). ${ }^{134}$ NMDA-induced retinal cell degeneration causes RGC loss via NMDAR, (GlunN2B and Glun2D) and activation glutamate transporter deficit. ${ }^{141-145}$ Cobalt chloride $(\mathrm{CoCl} 2)$-induced retinal cell degeneration has been provided by the use of $\mathrm{CoCl} 2$ which was reported as hypoxia-mimicking agent in both in vivo and in vitro studies. It causes photoreceptor cell loss via HIF-1alpha. ${ }^{146-148}$ Lightinduced retinal damage and related degeneration provides most of the essential features of human AMD. The exact pathogenetic mechanism of light-induced retinal degeneration and photoreceptor and RGC damage is not well-known. However, there are several pathogenetic mechanisms such as the induction of apoptosis in photoreceptors and RGCs, upregulation of pyruvate kinase isozyme type M2 (PKM2) for RGC loss and increased expression of some proton-sensing $G$ protein-coupled receptors. ${ }^{149-154}$

\section{Leber's congenital amaurosis}

Leber congenital amaurosis (LCA) is an inherited retinal disease that causes severe vision loss in infants. Leber congenital amaurosis is caused by a defect in rods and cones. Although LCA may be related to 18 gene mutations, great majority of the patients with LCA have an RPE65 deficiency. Currently, there are two animal models of RPE65 deficiency for LCA. The first one is the Swedish Briard dog model with a spontaneous mutation. ${ }^{155,156}$ Affected Briard dogs have a homozygous 4-bp deletion (485delAAGA) in canine RPE65 gene. In this model, severe visual impairment is similar to that in human LCA. ${ }^{157,158}$ The other is the mice model, a knockout of RPE65. The progressive retinal degeneration, severe visual loss, lackness of the rhodopsin photopigment, and accumulation of all-trans were detected in the both animals. ${ }^{155-158}$

\section{Retinal ischemia-reperfusion (RIR)}

Retinal ischemia, a common cause of irreversible visual impairment, is associated with various retinal diseases such as ischemic optic neuropathies, obstructive retinopathies, carotid occlusive disorders, diabetic retinopathy and glaucoma. ${ }^{159-164}$ Retinal ischemia occurs when there is an imbalance between the blood supply and the metabolic requirements of the retina and it results in cellular death. As the blood supply to retina and choroid is too similar to that in humans, the rats are frequently used for the studies in RIR models. The main methods of the induction of retinal ischemia in the animal include the raising the IOP, middle cerebral artery (MCA) occlusion, chronic carotid ligation, photo-thrombosis or photocoagulation of retinal vessels, central retinal artery (CRA) occlusion, and intravitreal or intravenous endothelin administration. ${ }^{159-164}$ Filamentous MCA occlusion is one of most commonly used method both focal cerebral and retinal ischemia models in rodents because the ophthalmic artery and is proximal to the origin of the MCA. ${ }^{162,163}$ As the ophthalmic artery arises from the internal carotid artery and it is located at the proximal region to the origin of MCA and predominantly supplies the inner retina, the MCA occlusion causes interruption of the vascular supply to the retina and allocular structures, consequently it results in retinal ischemia. ${ }^{164}$

\section{Central retinal artery occlusion (CRAO)}

In humans, CRAO causes severe retinal ischemia and consequently irreversible retinal damage in a few hours. CRAO model for transient retinal ischemia may be formed with photo-thrombosis of CRA using an intravenous injection of Rose Bengal and the irradiation of CRA with green laser or CRA ligation in rats. ${ }^{165}$ If Rose Bengal, a 
photosensitive dye, is irradiated by the laser; it causes oxygen free radicals and consequently the intraluminal thrombus formation and CRAO. In CRA ligation model, CRAO is created through placing a suture on the CRA and ciliary artery behind the eye globe, the passion of suture ends through a small plastic tube and pressing the tube against the CRA for induction for ischemia. ${ }^{166}$ Central retinal artery occlusion can also be obtained by injection of Endothelin-1 (ET-1) which is a potent vasoconstrictive drug. The injection of ET-1 is less invasive and has no need to any special equipment. Recent studies demonstrated that ET-1 showed similar effects on rabbit and cat eyes following the intravenous, intravitreal or subconjunctival administration, respectively. ${ }^{167-169}$

\section{Retinal vein occlusion}

Retinal vein occlusion is the second most common retinal vascular disease following diabetic retinopathy. ${ }^{170}$ Some methods including mechanical ligation, endothelin-1 injection and light coagulation for RVO animal models in rats, cats, or rabbits have been defined. However, laser photocoagulation with a photo sensitizer is currently the most common method to induce RVO in rats. ${ }^{171-174}$ Recently, another reproducible and reliable animal RVO model has been developed in rats and miniature pigs. In this model, RVO was induced by photo chemically-induced ischemia with erythrosin $\mathrm{B}$, and the main manifestations of human RVO were obtained. ${ }^{175,176}$ It has been well-known that that glutamate release and activation of NMDA and non-NMDA receptors play a significant role in retinal ischemic injury. ${ }^{135,170,177-182}$

\section{Conflicts of interest}

All authors declare their no conflicts of interest for the publication of this article.

\section{Funding}

None.

\section{References}

1. Dejneka NS, Rex TS, Bennett J. Gene Therapy and Animal Models for Retinal Disease. Dev Ophthalmol. 2003;37:188-198.

2. Iwata T, Tomarev S. Animal Models for Eye Diseases and Therapeutics. Sourcebook of Models for Biomedical Research. 2008; 279-287.

3. Grossniklaus HE, Kang SJ, Berglin L. Animal Models of Choroidal and Retinal Neovascularization. Prog Ret Eye Res. 2010; 29(6):500-519.

4. Williams DL. Animal Models for Ophthalmic Diseases In Human. In: Gelatt KN editors. Veterinary Ophthalmology. 2nd ed. Philadelphia, Lea \& Febiger, Pennsylvania, USA. 1991; p. 1237-1272.

5. Uemura A, Kusuhara S, Katsuta H, et al. Angiogenesis in the mouse retina: a model system for experimental manipulation. Exp Cell Res. 2006;12(5):676-683.

6. Grosskilaus HE, Wilson MW, Barron BC, et al. Anterior versus posterior intraocular melanoma: metastatic differences in a murine model. Arch Ophthalmol. 1996;114(9):1116-1120.

7. Singh AD, Topham A. Survival rates with uveal melanoma in the United States: 1973-1997. Ophthalmology. 2003;110(5):962-965.

8. Egan KM, Seddon JM, Glynn RJ, et al. Epidemiologic aspects of uveal melanoma. Surv Ophthalmol. 1988;32(4):239-251.

9. Neiderkon JY. Enucleation-induced metastasis of intraocular melanomas in mice. Ophthalmol. 1984;91(6):692-700.
10. Goldberg MF. Persistent fetal vasculature (PFV): an integrated interpretation of signs and symptoms associated with persistent hyperplastic primary vitreous (PHPV). Am J Ophthalmol. 1997;124(5):587-626.

11. Hu LK, Huh K, Gragoudas ES, et al. Establishment of pigmented choroidal melanomas in a rabbit model. Retina. 1994;14(3): 264-269.

12. Pineda R, Theodossiadis PG, Gonzalez VH, et al Establishment of a rabbit model of extrascleral extension of ocular melanoma. Retina. 1998;18(4):368-372.

13. Krause MH, Xiong J, Gragoudas ES, et al. Treatment of experimental choroidal melanoma with an Nd:yttrium-lanthanum-fluoride laser at 1047nm. Arch Ophthalmol. 2003;121(3):357-363.

14. Holly field JG, Kondo LK. Animal Models for Age-Related Macular Degeneration. In: Iok-Hou Pang. editors. Animal Models for Retinal Diseases, Neuromethods, Humana Press, Springer Science+ Business Media, USA. 2010;46:81-98.

15. Francois J, De Laey, JJ, Cambie E, et al. Neovascularization after argon laser photocoagulation of macular lesions. Am J Ophthalmol. 1975;79(2):206-210.

16. Lu F, Adelman RA. Are intravitreal bevacizumab and ranibizumab effective in a rat model of choroidal neovascularization? Graefes Arch Clin Exp Ophthalmol. 2009;247(2):171-177.

17. Yu L, Wu X, Cheng Z, Lee CV, LeCouter J, et al Interaction between bevacizumab and murine VEGF-A: a reassessment. Invest Ophthalmol Vis Sci. 2008;49(2):522-527.

18. Shen M, Yan M, Wang L, Zhang JJ, et al Experimental choroidal neovascularization induced by laser in the eyes of rhesus monkeys. Sichuan Da Xue Xиe Bao Yi Xиe Ban. 2008;39(4):567-569.

19. Ryan SJ. The development of an experimental model of subretinal neovascularization in disciform macular degeneration. Trans Am Ophthalmol Soc. 1979;77:707-745.

20. Ryan SJ, Subretinal neovascularization Natural history of an experimental model. Arch Ophthalmol. 1982;100(11):1804-1809.

21. Tolentino MJ, Husain D, Theodosiadis P, et al Angiography of fluoresceinated anti-vascular endothelial growth factor antibody and dextrans in experimental choroidal neovascularization. Arch Ophthalmol. 2000;118(1):78-84.

22. Shen WY, Lee SY, Yeo I, et al Predilection of the macular region to high incidence of choroidal neovascularization after intense laser photocoagulation in the monkey. Arch Ophthalmol. 2004;122(3):353360 .

23. Okamoto N, Tobe T, Hackett SF, et al Transgenic mice with increased expression of vascular endothelial growth factor in the retina: A new model of intraretinal and subretinal neovascularization. Am J Pathol. 1997;151(1):281-291.

24. Schwesinger $\mathrm{C}$, Yee $\mathrm{C}$, Rohan RM, et al. Intrachoroidal neovascularization in transgenic mice overexpressing vascular endothelial growth factor in the retinal pigment epithelium. Am J Pathol. 2001;158(3):1161-1172.

25. Baffi J, Byrnes G, Chan CC, et al. Choroidal neovascularization in the rat induced by adenovirus-mediated expression of vascular endothelial growth factor. Invest Ophthalmol Vis Sci. 2000;41(11):3582-3589.

26. Zhang Y, Fortune B, Atchaneeyasakul LO, et al. Natural history and histology in a rat model of laser-induced photothrombotic retinal vein occlusion. Curr. Eye Res. 2008;33(4):365-376.

27. Gholipour MA, Kanavi MR, Ahmadieh H, et al. Intravitreal Topotecan Inhibits Laser-induced Choroidal Neovascularization in a Rat Model. $J$ Ophthalmic Vis Res. 2015;10(3):295-302. 
28. Zacks DN, Hanninen V, Pantcheva M, et al. Caspase Activation in an Experimental Model of Retinal Detachment. Invest Ophthalmol Vis Sci. 2003;44(3):1262-1267

29. Zacks DN, Han Y, Zeng Y, et al. Activation of Signaling Pathways and Stress-Response Genes in an Experimental Model of Retinal Detachment. Invest Ophthalmol Vis Sci. 2006;47(4):1691-1695.

30. Nakazawa T, Matsubara A, Noda K, et al. Characterization of cytokine responses to retinal detachment in rats. Mol Vis. 2006;12: 867-878.

31. Nakazawa T, Kayama M, Ryu M, et al. Tumor Necrosis Factor-Mediates Photoreceptor Death in a Rodent Model of Retinal Detachment. Invest Ophthalmol Vis Sci. 2011;52(3):1384-1391.

32. Hisatomi T, Sakamoto T, Murata T, et al. Relocalization of apoptosisinducing factor in photoreceptor apoptosis induced by retinal detachment in vivo. Am J Pathol. 2001;158(4):1271-1278.

33. Hisatomi T, Sakamoto T, Goto Y, et al Critical role of photoreceptor apoptosis in functional damage after retinal detachment. Curr. Eye Res. 2002;24(3):161-172

34. Nakazawa T, Hisatomi T, Nakazawa Y, et al. Monocyte chemoattractan protein 1 mediates retinal detachment-induced photoreceptor apoptosis. Proc Natl Acad Sci. 2007;104(7):2425-2430.

35. Trichonas G, Murakami Y, Thanos A, et al. Receptor interacting protein kinases mediate retinal detachment-induced photoreceptor necrosis and compensate for inhibition of apoptosis. Proc Natl Acad Sci. 2010;107(50):21695-21700.

36. Murakami Y, Notomi S, Hisatomi T, et al Photoreceptor cell death and rescue in retinal detachment and degenerations. Prog Retin Eye Res. 2013;37:114-140.

37. Mantopoulos D, Murakami Y, Comander J, et al. Tauroursodeoxycholic acid (TUDCA) protects photoreceptors from cell death after experimental retinal detachment. PLoS One. 2011;6(9):e24245.

38. Yang L, Bula D, Arroyo JG, et al. Preventing retinal detachment-associated photoreceptor cell loss in Bax-deficient mice. Invest Ophthalmol Vis Sci. 2004;45(2):648-654.

39. Cebulla CM, Ruggeri M, Murray TG, et al. Spectral domain optica coherence tomography in a murine retinal detachment model. Exp Eye Res. 2010;90(4):521-527.

40. Secondi R, Kong J, Blonska AM, et al. Fundus Autofluorescence Findings in a Mouse Model of Retinal Detachment. Invest Ophthalmol Vis Sci. 2012;53(9):5190-5197.

41. Stieger K, Lorenz B. Gene therapy for vision loss: recent developments. Discov Med. 2010;10(54):425-433.

42. Yokoi K, Kachi S, Zhang HS, et al. Ocular gene transfer with self-complementary AAV vectors. Invest Ophthalmol Vis Sci. 2007;48(7):3324-3328

43. Kong F, Li W, Li X, et al. Self-complementary AAV5 vector facilitates quicker transgene expression in photoreceptor and retinal pigment epithelial cells of normal mouse. Exp Eye Res. 2010;90(5):546-554.

44. Pang JJ, Lauramore A, Deng WT, et al. Comparative analysis of in vivo and in vitro AAV vector transduction in the neonatal mouse retina: effects of serotype and site of administration. Vision Res. 2008;48(3):377-385.

45. Cideciyan AV. Leber congenital amaurosis due to RPE65 mutations and its treatment with gene therapy. Prog Retin Eye Res. 2010;29(5):398-427.

46. Lewis GP, Sethi CS, Linberg KA, et al. Experimental retinal reattachment: a new perspective. Mol Neurobiol. 2003;28(2):159-175.

47. Lewis GP, Chapin EA, Luna G, et al. The fate of Muller's glia following experimental retinal detachment: nuclear migration, cell division, and subretinal glial scar formation. Mol Vis. 2010;16:1361-1372.
48. Jackson TL, Hillenkamp J, Williamson TH, et al. An experimental model of rhegmatogenous retinal detachment: surgical results and glial cell response. Invest Ophthalmol Vis Sci. 2003;44(9):4026-4034.

49. Hollborn M, Francke M, Iandiev I, et al. Early activation of inflammationand immune response-related genes after experimental detachment of the porcine retina. Invest Ophthalmol Vis Sci. 2008;49(3):1262-1273.

50. Torbidoni V, Iribarne M, Suburo A. Endothelin receptors in light-induced retinal degeneration. Exp Biol Med (Maywood) 2008;231(6):1095-1100.

51. Nour M, Quiambao AB, Peterson WM, et al. P2Y(2) receptor agonist INS37217 enhances functional recovery after detachment caused by subretinal injection in normal and rds mice. Invest Ophthalmol Vis Sci. 2003;44(10):4505-4514.

52. Matsumoto H, Miller JW, Vavvas DG. Retinal Detachment Model in Rodents by Subretinal Injection of Sodium Hyaluronate. J Vis Exp. $2013 ; 79$.

53. Machemer R. Experimental retinal detachment in the owl monkey. IV. The reattached retina. Am J Ophthalmol. 1968;66(6): 1075-1091.

54. Zeng R, Zhang Y, Shi F, et al. A novel experimental mouse model of retinal detachment: complete functional and histologic recovery of the retina. Invest Ophthalmol Vis Sci. 2012;53(3):1685-1695.

55. Sadaka A, Giuliari GP. Proliferative vitreoretinopathy: current and emerging treatments. Clin Ophthalmol. 2012;6:1325-1333.

56. Wong CA, Potter MJ, Cui JZ, et al. Induction of proliferative vitreoretinopathy by a unique line of human retinal pigment epithelial cells. Can J Ophthalmol. 2002;37(4):211-220.

57. Umazume K, Barak Y, McDonald K, et al. Proliferative vitreoretinopathy in the Swine-a new model. Invest Ophthalmol Vis Sci. 2012;53(8):49104916.

58. Frenzel E, Neely KA, Walsh AW, et al. A new model of proliferative vitreoretinopathy. Invest Ophthalmol Vis Sci. 1998;39(11): 2157-2164.

59. Cantó Soler MV, Gallo JE, Dodds RA, et al. A mouse model of proliferative vitreoretinopathy induced by dispase. Exp Eye Res. 2002;75(5):491-504.

60. Iverson DA, Katsura H, Hartzer MK, et al. Inhibition of intraocular fibrin formation following infusion of low-molecular-weight heparin during vitrectomy. Arch Ophthalmol. 1991;109(3):405-409.

61. Berger AS, Cheng CK, Pearson PA, et al. Intravitreal sustained release corticosteroid-5-fluorouracil conjugate in the treatment of experimental proliferative vitreoretinopathy. Invest Ophthalmol Vis Sci. 1996;37(11):2318-2325.

62. Garcia-Layana A, Pastor JC, Saornil MA, et al. Porcine model of proliferative vitreoretinopathy with platelets. Curr Eye Res. 1997;16(6):556-563

63. Takahashi M, Refojo MF, Nakawaga M, et al. Antiproliferative effect of retinoic acid in 1\% sodium hyaluronate in an animal model of PVR. Curr Eye Res. 1997;16(7):703-709.

64. Larrosa JM, Veloso AA, Leong FL, et al. Antiproliferative effect of intravitreal alpha-tocopherol and alpha-tocopherol-succinate in a rabbit model of PVR. Curr Eye Res. 1997;16(10):1030-1035.

65. Sato S, Kador PF. NADPH-dependent reductase of the dog lens. Exp Eye Res. 1990;50(6):629-634

66. Adrian MT, Miller CM, Zhu L. Animal Models of Diabetic Retinopathy. In: Animal Models for Retinal Diseases, Neuromethods, Iok-Hou Pang and Abbot F. Clark. editors. Humana Press, Springer Science+Business Media. 2010; 46:113-138.

67. Engerman R1, Bloodworth JBM. Experimental diabetic retinopathy in dogs. Arch Ophthalmol. 1965;73:205-210. 
68. Jiang X, Yang L, Luo Y. Animal Models of Diabetic Retinopathy. Curr Eye Res. 2015;40(8):761-771.

69. Fletcher EL, Jobling AI, Vessey KA, et al. Animal models of retinal disease. Prog Mol Biol Transl Sci. 2011;100:211-286.

70. Link FC, Ross FC. Zebrafish Models of Retinal Disease. Annu Rev Vis Sci. 2015;1:125-153.

71. Sugita G, Tano Y, Machemer R. Experimental neovascularization of the retina. Int Ophthalmol. 1980;2(1):33-37.

72. Tano Y, Chandler DB, Machemer R. Retinal neovascularization after intravitreal fibroblast injection. Am J Ophthalmol. 1981;92(1):103-109.

73. Tano Y, Chandler DB, Machemer R. Vascular casts of experimental retinal neovascularization. Am J Ophthalmol. 1981;92(1): 110-120.

74. Hitchins CA, Grierson I, Hiscott PS. The effects of injections of cultured fibroblasts into the rabbit vitreous. Graefes Arch Clin Exp Ophthalmol. 1985;223(5):237-249.

75. Ophir A, Blumenkranz MS, Clafin AJ. Experimental intraocular proliferation and neovascularization. Am J Ophthalmol. 1982;94(4):450457.

76. Hemo I, Maftzir G, Ben Ezra D. Retinal Neovascularization. Second International Symposium on Ocular Circulation and Neovascularization. Baltimore, Wilmer Institute, USA. 1989; p. 36.

77. Hamilton AM, Marshall J, Kohner EM, et al. Retinal new vessel formation following experimental vein occlusion. Exp Eye Res. 1975;20(6):493497.

78. Jabbour NM, Nork TM, et al. Extraretinal neovascularization model system in the rhesus monkey. ARVO Abstracts. Invest Ophthalmol Vis Sci. 1989; 0: 392.

79. Ashton N, Ward B, Serpell G. Effect of oxygen on developing retinal vessels with particular reference to the problem of retrolental fibroplasias. Br J Ophthalmol. 1954;38(7):397-432.

80. Patz A . Clinical and experimental studies on retinal neovascularization. Am J Ophthalmol. 1982;94(6):715-743.

81. Ashton N, Ward B, Serpell G. Role of oxygen in the genesis of retrolental fibroplasias. Br J Ophthalmol. 1953;37(9):513-520.

82. Finkelstein D, Bren S, PatzA, et al. Experimental retinal neovascularization induced by intravitreal tumors. Am J Ophthalmol. 1977;83(5):660-664.

83. Weber ML, Mancini MA, Frank RN. Retinovitreai neovascularization in the Royal College of Surgeons rat. Curr Eye Res. 1989;8(1):61-74.

84. Frank RN, Mancini MA. Presumed retinovitreai neovascularization in dystrophic retinas of spontaneously hypertensive rats. Invest Ophthalmol Vis Sci. 1986;27(3):346-355.

85. Antoszyk AN, Gottlieb JL, Casey RC, et al. An experimental model of preretinal neovascularization in the rabbit. Invest Ophthalmol Vis Sci. 1991;32(1):46-52.

86. Yannuzzi LA. Type A behavior and central serous chorioretinopathy. Retina. 2012;32(Suppl 1):709.

87. Yoshioka H. Experimental Central Serious Chorioretinopathy II: Further Clinical Findings, The Kurume Medical Journal. 1981;28(3):189-196.

88. Yoshioka H, Katsume Y. Experimental central serous chorioretinopathy. III: ultrastructural findings. Jpn J Ophthalmol. 1982;26(4): 397-409.

89. Yoshioka H, Katsume Y, Akune H. Experimental central serous chorioretinopathy in monkey eyes: fluorescein angiographic findings. Ophthalmologica. 1982;185(3):168-178.
90. Nicholson B, Noble J, Forooghian F, et al. Central serous chorioretinopathy: update on pathophysiology and treatment. Surv Ophthalmol. 2013;58(2):103-126.

91. Yoshioka H, Katsume Y, Akune H. Studies on experimental central serous chorioretinopathy. Fluorescein angiography and histopathology during the course of spontaneous remission. Nihon Ganka Gakkai Zasshi. 1984;88(5):819-828.

92. Jampol LM, Weinreb R, Yannuzi L. Involvement of corticosteroids and catecholamines in the pathogenesis of central serous chorioretinopathy: a rationale for new treatment strategies. Ophthalmology. 2002;109(10):1765-1766.

93. Pryds A, Sander B, Larsen M. Characterization of subretinal fluid leakage in central serous chorioretinopathy. Invest Ophthalmol Vis Sci. 2010;51(11):5853-5857.

94. Hayreh SS, Servais GE, Virdi PS, et al. Fundus lesions in malignant hypertension: III-arterial blood pressure, biochemical, and fundus changes. Ophthalmology. 1986;93(1):45-59.

95. Wong TY, Klein R, Klein BE, et al. Retinal microvascular abnormalities and their relationship with hypertension, cardiovascular disease, and mortality. Surv Ophthalmol. 2001;46(1):59-80.

96. Tso MO, Jampol LM. Pathophysiology of hypertensive retinopathy. Ophthalmology. 1982;89(10):1132-1145.

97. Wong TY, Mitchell P. Hypertensive retinopathy. $N$ Engl J Med. 2004;351(22):2310-2317.

98. Chang-Ling T, Tout S, Hollander H, et al. Vascular changes and their mechanisms in the feline model of retinopathy of prematurity. Invest Ophthalmol Vis Sci. 1992;33(7):2128-2147.

99. Reichhart N, Haase N, Crespo-Garcia S, et al. Hypertensive retinopathy in a transgenic angiotensin-based model. Clin Sci (Lond). 2016;130(13):1075-1088.

100. Feihl F, Liaudet L, Waeber B, et al. Hypertension: a disease of the microcirculation? Hypertension. 2006;48(6):1012-1017.

101. Nørrelund H, Christensen KL, Samani NJ, et al. Early narrowed afferent arteriole is a contributor to the development of hypertension. Hypertension. 1994;24(3):301-308.

102. Levy BI, Ambrosio G, Pries AR, et al. Microcirculation in hypertension: a new target for treatment? Circulation. 2001;104(6):735740.

103. Garner A, Ashton N, Tripathi R, et al. Pathogenesis of hypertensive retinopathy. An experimental study in the monkey. $\mathrm{Br} J$ Ophthalmol. 1975;59(1):3-44.

104. McDonald L, Lee GR, Degooyer TE, et al. Effects of an endothelin receptor antagonist on a model of hypertensive retinopathy. Ophthalmic Res. 2010;43(2):99-107.

105. Susan E. Yanni, John S. Penn. Animal Models of Retinopathy of Prematurity. In: Animal Models for Retinal Diseases, Neuromethods, Iok-Hou Pang and Abbot F. Clark. editors. Humana Press, Springer Science+Business Media. 2010;46:99-111.

106. Smith LE, Wesolowski E, McLellan A, et al. Oxygen-induced retinopathy in the mouse. Invest Ophthalmol Vis Sci. 1994;35(1):101-111.

107. Penn JS, Henry MM, Tolman BL. Exposure to alternating hypoxia and hyperoxia causes severe proliferative retinopathy in the newborn rat. Pediatr Res. 1994;36(6):724-731.

108. Penn JS, Tolman BL, Lowery LA. Variable oxygen exposure causes preretinal neovascularization in the newborn rat. Invest Ophthalmol Vis Sci. 1993;34(3):576-585. 
109. McLeod DS, Brownstein R, Lutty GA. Vaso-obliteration in the canine model of oxygen-induced retinopathy. Invest Ophthalmol Vis Sci. 1996;37(2):300-311.

110.Cao R, Jensen LD, Söll I, Hauptmann G, Cao Y (2008) Hypoxia-induced retinal angiogenesis in zebrafish as a model to study retinopathy. PLoS One. 3(7):2748.

111.Lutty GA, McLeod DS, Bhutto I, et al. Effect of VEGF Trap on normal retinal vascular development and oxygen-induced retinopathy in the dog. Invest Ophthalmol Vis Sci. 2011;52(7):4039-4047.

112.Hartnett ME, Penn JS. Mechanisms and management of retinopathy of prematurity. $N$ Engl J Med. 2012;367(26):2515-2526.

113. Hartnett ME. Studies on the pathogenesis of avascular retina and neovascularization into the vitreous in peripheral severe retinopathy of prematurity (an American Ophthalmological Society thesis). Trans Am Ophthalmol Soc. 2010;108: 96-119.

114.Pierce EA, Foley ED, Smith LE. Regulation of vascular endothelial growth factor by oxygen in a model of retinopathy of prematurity. Arch Ophthalmol. 1996;114(10):1219-1228.

115.Flower RW, Balke DAS. Retrolental fibroplasia: role of of the prostaglandin cascade in the pathogenesis of oxygen induced retinopathy in the newborn beagle. Pediatr Res. 1981;15(9):1293-1302.

116.Ashton N, Tripathi B, Knight G. Effect of oxygen on the developing retinal vessels of the rabbit. II. In vivo experiments. Exp Eye Res. 1972; 14(3):221-232.

117.Penn JS, Rajaratnem VS, Collier RJ, et al. The effect of an angiostatic steroid on neovascularization in a rat model of retinopathy of prematurity. Invest Ophthalmol Vis Sci. 2001;42(1):283-290.

118. Cunningham S, McColm JR, Wade J, et al. A novel model of retinopathy of prematurity simulating preterm oxygen variability in the rat. Invest Ophthalmol Vis Sci. 2000;41(13):4275-4280.

119. Cunningham S. Computerised physiological trend monitoring in neonatal intensive care. University of Edinburgh. 1993

120. Di Fiore JM, Kaffashi F, Loparo K, et al. The relationship between patterns of intermittent hypoxia and retinopathy of prematurity in preterm infants. Pediatr Res. 2012;72(6):606-612.

121. Early Treatment for Retinopathy of Prematurity Cooperative Group Revised indications for the treatment of retinopathy of prematurity: results of the Early Treatment for Retinopathy of Prematurity randomized trial. Arch Ophthalmol. 2003;121(12):1684-1694.

122. Juárez CP, Muiño JC, Guglielmone H, et al. Experimental retinopathy of prematurity: angiostatic inhibition by nimodipine, ginkgo-biloba, and dipyridamole, and response to different growth factors. Eur J Ophthalmol. 2000;10(1):51-59.

123. Humphries MM, Rancourt D, Farrar GJ, et al. Retinopathy induced in mice targeting disruption of the rhodopsin gene. Nature Genet. $1997 ; 15(2): 216-219$

124. Jiang Y, Wang H, Culp D, et al. Targeting Muller cell-derived VEGF164 to reduce intravitreal neovascularization in the rat model of retinopathy of prematurity. Invest Ophthalmol Vis Sci. 2014;55(2):824831 .

125. Rivera JC, Sapieha P, Joyal JS, et al. Understanding retinopathy of prematurity: update on pathogenesis. Neonatology. 2011 100(4):343-353.

126. Gerhardt H, Golding M, Fruttiger M, et al. VEGF guides angiogenic sprouting utilizing endothelial tip cell filopodia. $J$ Cell Biol. 2003;161(6):1163-1177.
127. Wang H, Smith GW, Yang Z, et al. Short hairpin RNAmediated knockdown of VEGFA in Muller cells reduces intravitreal neovascularization in a rat model of retinopathy of prematurity. $A m \mathrm{~J}$ Pathol. 2013;183(3):964-974.

128. Wang H, Yang Z, Jiang Y, et al. Quantitative analyses of retinal vascular area and density after different methods to reduce VEGF in a rat model of retinopathy of prematurity. Invest Ophthalmol Vis Sci. 2014;55(2):737-744

129. Nair RM, Kaliki S, Vemuganti GK. Animal models in retinoblastoma research. Saudi J Ophthalmol. 2013;27(3):141-146.

130. Cavenee WK, Dryja TP, Phillips RA, et al. Expression of recessive alleles by chromosomal mechanisms in retinoblastoma. Nature. 1983;305(5937):779-784

131. Hurwitz MY, Marcus KT, Chevez-Barrios P, et al. Suicide gene therapy for treatment of retinoblastoma in a murine model. Hum Gene Ther. 1999;10(3):441-448.

132. Albert DM, Gonder JR, Papale J, et al. Induction of ocular neoplasms in Fischer rats by intraocular injection of nickel subsulphide. Invest Ophthalmol Vis Sci. 1982;22(6):768-782.

133. O'Brien JM, Marcus DM, Bernards R, et al. A transgenic mode for trilateral retinoblastoma. Arch Ophthalmol. 1990;108(8): 1145-1151.

134. Samardzija M, Neuhauss SCF, Joly S, et al. Animal Models for Retinal Degeneration. In: Animal Models for Retinal Diseases, Neuromethods, Iok-Hou Pang \& Abbot F Clark. Editors. Humana Press, Springer Science+Business Media, Germany. 2010;46: 51-80.

135. Osborne NN, Casson RJ, Wood JP, et al, Retinal ischemia: Mechanisms of damage and potential therapeutic strategies. Prog. Retin. Eye Res. 2004;23(1):91-147.

136. Fontaine V, Mohand-Said S, Hanoteau N, et al. Neurodegenerative and neuroprotective effects of tumor Necrosis factor (TNF) in retinal ischemia: Opposite roles of TNF receptor 1 and TNF receptor $2 . J$ Neurosci. 2002;22(7):RC216.

137. Amsterdam A, Hopkins N. Mutagenesis strategies in zebrafish for identifying genes involved in development and disease. Trends Genet. 2002;22(9):473-478.

138. Gaiano N, Amsterdam A, Kawakami K, et al. Insertional mutagenesis and rapid cloning of essential genes in zebrafish. Nature. 1996;383(6603):829-832.

139. Nasevicius A, Ekker SC. Effective targeted gene 'knockdown' in zebrafish. Nat Genet. 2000;26:216-220.

140. Robu ME, Larson JD, Nasevicius A, et al. p53 activation by knockdown technologies. PLoS Genet. 2007;3(5):e78.

141. Lam TT, Abler AS, Kwon JM, et al. N-methyl-D-aspartate (NMDA)-induced apoptosis in rat retina. Invest Ophthalmol Vis Sci. 1999;40(10):2391-2397.

142. Izumi Y, Hammerman SB, Kirby CO, et al. Involvement of glutamate in ischemic neurodegeneration in isolated retina. Vis Neurosci. 2003;20(2):97-107

143. Bai N, Aida T, Yanagisawa M, et al. NMDA receptor subunits have different roles in NMDA-induced neurotoxicity in the retina. Mol Brain. 2013;6:34.

144. Ferreira IL, Duarte CB, Carvalho AP. Ca2+ influx through glutamate receptor-associated channels in retina cells correlates with neuronal cell death. Eur J Pharmacol. 1996;302(1-3):153-162. 
145. Harada T, Harada C, Nakamura K, et al. The potential role of glutamate transporters in the pathogenesis of normal tension glaucoma. J Clin Invest. 2007;117(7):1763-1770.

146. Vengellur A, Woods BG, Ryan HE, et al. Gene expression profiling of the hypoxia signaling pathway in hypoxia-inducible factor $1 \alpha$ null mouse embryonic fibroblasts. Gene Expr. 2003;11(3-4):181-197.

147. Yuan Y, Hilliard G, Ferguson T, et al. Cobalt inhibits the interaction between hypoxia-inducible factor-alpha and von Hippel-Lindau protein by direct binding to hypoxia-inducible factor- $\alpha$. J Biol Chem. 2003;278(18):15911-15916.

148. Hara A, Taguchi A, Niwa M, et al. Localization of septin 8 in murine retina, and spatiotemporal expression of septin 8 in a murine model of photoreceptor cell degeneration. Neurosci Lett. 2007;423(3):205-210.

149. Yang X, Chen H, Zhu M, et al. Up-Regulation of PKM2 Relates to Retinal Ganglion Cell Apoptosis After Light-Induced Retinal Damage in Adult Rats. Cell Mol Neurobiol. 2015;35(8):1175-1186.

150. Marc RE, Jones BW, Watt CB, et al. Extreme retinal remodeling triggered by light damage: Implications for age related macular degeneration. Mol Vis. 2008;14:782-806.

151. Wenzel A, Grimm C, Samardzija M, et al. Molecular mechanisms of light-induced photoreceptor apoptosis and neuroprotection for retinal degeneration. Prog Retin Eye Res. 2005;24(2):275-306.

152. Ail D, Rüfenacht V, Caprara C, et al. Increased expression of the proton-sensing $\mathrm{G}$ protein-coupled receptor Gpr65 during retinal degeneration. Neuroscience. 2015;301:496-507.

153. Niwa M, Aoki H, Hirata A, et al. Retinal Cell Degeneration in Animal Models. Int J Mol Sci. 2016;17(1).

154. Hafezi F, Grimm C, Simmen BC, et al. Molecular ophthalmology: an update on animal models for retinal degenerations and dystrophies. $\mathrm{Br} J$ Ophthalmol. 2000;84(8):922-927.

155. Narfstrom K, Wrigstad A, Nilsson SE. The Briard dog: A new animal model of congenital stationary night blindness. Br J Ophthalmol. 1989;73(9):750-756.

156. Wrigstad A. Hereditary dystrophy of the retina and the retinal pigment epithelium in a strain of Briard dogs: A clinical, morphological and electrophysiological study, Linköping University Medical Dissertations.1994.

157. Veske A, Nilsson SE, Narfstrom K, et al. Retinal dystrophy of Swedish Briard/Briard-beagle dogs is due to a 4-bp deletion in RPE65. Genomics. 1999;57(1):57-61.

158. Aguirre GD, Baldwin V, Pearce-Kelling S, et al. Congenital stationary night blindness in the dog: Common mutation in the RPE65 gene indicates founder effect. Mol Vis. 1998;4: 23.

159. Tamura A, Graham DI, McCulloch J, et al. Focal cerebral ischaemia in the rat: 1. Description of technique and early neuropathological consequences following middle cerebral artery occlusion. J Cereb Blood Flow Metab. 1981;1(1):53-60.

160. Longa EZ, Weinstein PR, Carlson S, et al. Reversible middle cerebral artery occlusion without craniectomy in rats. Stroke. 1989;20(1):84-91.

161. D'Onofrio PM, Koeberle PD. What can we learn about stroke from retinal ischemia models? Acta Pharmacol Sin. 2013;34(1):91-103.

162. Koizumi J, Yoshida Y, Nakazawa T, et al. Experimental studies of ischemic brain edema. I. A new experimental model of cerebral embolism in which recirculation can introduced into the ischemic area. Jpn J Stroke. 1986;8(1):1-8.

163. Steele EC, Guo Q, Namura S. Filamentous middle cerebral artery occlusion causes ischemic damage to the retina in mice. Stroke.2008;39(7):2099-2104.
164. Muthaian R, Minhas G, Anand A. Pathophysiology of stroke and stroke-induced retinal ischemia: Emerging role of stem cells. $J$ Cell Physiol. 2012;227(3):1269-1279.

165. Daugeliene L, Niwa M, Hara A, et al. Transient ischemic injury in the rat retina caused by thrombotic occlusion-thrombolytic reperfusion. Invest Ophthalmol Vis Sci. 2000;41(9):2743-2747.

166. Prasad SS, Kojic L, Wen YH, et al. Retinal gene expression after central retinal artery ligation: Effects of ischemia and reperfusion. Invest Ophthalmol Vis Sci. 2010;51(12):6207-6219.

167. Granstam E, Wang L, Bill A. Ocular effects of endothelin-1 in the cat. Curr Eye Res. 1992;11(4):325-332.

168. Masuzawa K, Jesmin S, Maeda S, et al. A model of retinal ischemiareperfusion injury in rats by subconjuctival injection of Endothelin-1. Experimental Biology and Medicine. 2006;231(6):1085-1089.

169. Yu DY, Su EN, Cringle SJ, et al. Effect of betaxolol, timolol and nimodipine on human and pig retinal arterioles. Exp Eye Res. 1998;67(1):73-81.

170. Wong TY, Scott IU. Retinal-vein occlusion. $N$ Engl J Med. 2010; 363(22):2135-2144.

171. Hayashi A, Imai K, Kim HC, et al. Activation of protein tyrosine phosphorylation after retinal branch vein occlusion in cats. Invest Ophthalmol Vis Sci, 1997;38(2):372-380.

172. Takei K, Sato T, Nonoyama T, et al. A new model of transient complete obstruction of retinal vessels induced by endothelin-1 injection into the posterior vitreous body in rabbits. Graefes Arch Clin Exp Ophthalmol. 1993;231(8):476-481.

173. Linner E. Occlusion of the retinal veins in rabbits induced by light coagulation. Acta Ophthalmol. 1961;39(4):739-740.

174. Zhang Y, Fortune B, Atchaneeyasakul LO, et al. Natural history and histology in a rat model of laser-induced photothrombotic retinal vein occlusion. Curr Eye Res. 2008;33(4):365-376.

175. Chen W, Wu Y, Zheng M, et al. Establishing an experimental rat model of photodynamically-induced retinal vein occlusion using erythrosine B. Int J Ophthalmol. 2014;7(2):232-238.

176. Pournaras CJ, Petropoulos IK, Pournaras JA, et al. The rationale of retinal endovascular fibrinolysis in the treatment of retinal vein occlusion: From experimental data to clinical application. Retina. 2012;32(8):15661573 .

177. Kwong Kwong JM, Caprioli J. Animal Models of Retinal Ischemia. In: Animal Models for Retinal Diseases, Neuromethods, Iok-Hou Pang $\&$ Abbot F Clark. editors. Humana Press, Springer Science+Business Media, Germany. 2016;46: 191-206.

178. Minhas G, Anand A. Animal Models of Retinal Ischemia In: Brain Injury-Pathogenesis, Monitoring, Recovery and Management, Prof. Amit Agrawal. 2011;153-174.

179. Minhas G, Morishita R, Anand . Preclinical models to investigate retinal ischemia: advances and drawbacks. Front Neurol. 2012;3:75.

180. Minhas G, Morishita R, Shimamura M, et al. Modeling transient retinal ischemia in mouse by ligation of pterygopalatine artery. Ann Neurosci. 2015;22(4):222-225.

181. Katz ML, Redmond TM. Effect of Rpe 65 knockout on accumulation of lipofuscin fluorophores in the retinal pigment epithelium. Invest Ophthalmol Vis Sci. 2001;42(12):3023-3030.

182. Virdi PS, Hayreh SS. Ocular neovascularization with retinal vascular occlusion: I. Association with experimental retinal vein occlusion. Arch Ophthalmol. 1982;100(2):331-341. 